\title{
In vivo propagation responses of sugarcane (sacharum officinarum I) genotypes at metahara sugar estate of Ethiopia
}

\begin{abstract}
In vivo propagation of micropropagated sugarcane plants of three selected sugarcane genotypes was carried out with the objective of evaluating their proliferation responses to BAP. Accordingly, six levels of BAP $\left(0,0.5,1,1.5,2\right.$ and $\left.2.5 \mathrm{mgL}^{-1}\right)$ with three sugarcane genotypes in a completely randomized design with $6 \times 3$ factorial treatment combination arrangements were tested. Data on the number of tillers per shoot, average shoot length $(\mathrm{cm})$ and number of leaves per shoot were collected after 60 days of planting on white polyethylene bag having $10 \mathrm{~cm}$ height and $8 \mathrm{~cm}$ diameter filled with soil, compost and sand at the ratios of 8:3:2 respectively. Analysis of variance revealed that the interaction effects of BAP and the sugarcane genotypes was very highly significant $(\mathrm{P}<0.0001)$ on the response variables tested. In sugarcane genotype C123-81, the optimum number of tillers per shoot (4.00) and average shoot length $(30.67 \mathrm{~cm})$ were recorded on $1 \mathrm{mgL}^{-1} \mathrm{BAP}$ while the maximum number of leaves $(6.00)$ was obtained at 0.5 and $1 \mathrm{mgL}^{-1}$. In sugarcane genotype C86-156, the optimum number of tillers per shoot (3.53) and number of leaves per shoot (7.00) were obtained at $1.5 \mathrm{mgL}^{-1} \mathrm{BAP}$ while the maximum average shoot length was observed at $1 \mathrm{mgL}^{-1}$. In sugarcane genotype SP70-1284, the maximum average shoot length $(32.67 \mathrm{~cm})$ and highest number of leaves per shoot (6.53) were obtained at $1 \mathrm{mgL}^{-1}$ BAP while the optimum number of tillers per shoot (4.67) was recorded at $1 \mathrm{mgL}^{-1}$ BAP. Therefore, from this result it can be concluded that, using this result, on average a plantlet can produce 4 tillers per shoot within a month and can reduce plantlets procurement cost by $25 \%$.
\end{abstract}

Keywords: in vivo propagation, sugarcane genotypes, C132-81, C86-156, SP701284
Volume 2 Issue 5 - 2017

\author{
Terefe G,' Sunil TH,' Belay Tolera² \\ 'Department of Biological Sciences, Dilla University, Ethiopia \\ ${ }^{2}$ Wonji Research and Development Center, Ethiopia
}

Correspondence: Belay Tolera, Ethiopian Sugar Corporation, Research and Development Center, Research Directorate, variety Improvement Research Program, Wonji Research and Development Center,Wonji, Ethiopia, Fax+25I-222200I44, Tel+25I-910181644,

Email belaytolera@yahoo.com, belaytolera2016@gmail.com

Received: January 10, 2017 | Published: March 23, 2017
Abbreviations: BAP, 6-benzylaminopurine; REGWQ, ryan-einot-gabriel-welsch; ANOVA, analysis of variance; IVPT, in vivo propagation technology; $\mathrm{CV}$, coefficient of variation; SE, standard error

\section{Introduction}

Sugarcane is a perennial grass which produces seed under suitable conditions, but for commercial production, it is propagated from stalk cuttings. Propagation through stalk cuttings is the traditional method of sugarcane propagation in which stalk cuttings containing one or more buds, termed setts are used for commercial planting. ${ }^{1}$ The Ethiopian Sugar Industry used this traditional method of propagation alone for the last 50 years till 2012. However, under the new plan of the Industry to expand the existing farms and establishment of vast sugarcane plantation projects with many high crushing capacity sugar factories, the tradition propagation method alone was seen to have various draw backs. Among these, availability of enough amount of quality disease free planting material within short time, transport of bulky unclean seed cane from existing farms to the remote project farms, the low rate of propagation(usually 1:10), lack of methods for fast commercialization of improved and adapted varieties, obsolation of productive commercial varieties due to disease, lack of alternative techniques for rejuvenation and disease cleansing of the old contaminated sugarcane varieties were the major limitations identified as challenges to the vast expansion and new development plans..$^{2-3}$
With a view to minimize the challenges, micropropagation technology was adopted and implemented to supplement the tradition method of sugarcane propagation in all sugar estates and projects. Microproagation Technology is a technique through which group of genetically identical plants all derived from a selected individual multiply vegetatively and rapidly by aseptic culture of meristematic regions under defined nutritional and controlled environmental conditions in vitro. ${ }^{4}$ Nowadays, unlike the traditional propagation method, it is the only practical means of achieving rapid and large scale production of disease free quality planting materials in sugarcane $^{5-7}$ and alternative approach for fast multiplication of a genotype in its original form. It is very effective in entire disease cleansing, rejuvenation and subsequent mass propagation of well adapted and promising varieties facing gradual deterioration in yield, quality and vigor due to accumulation of pathogens during prolonged vegetative cultivation and hence sustains the productive potential of sugarcane crops for a longer period. ${ }^{8-9}$ Furthermore, micropropagated sugarcane plants were reported to give superior in cane and sugar yield as compared to their donors under similar agronomic management systems. ${ }^{10-14}$

However, the Ethiopian Sugar Corporation is procuring the micropropagated sugarcane plantlets from different organizations where the cost of procurement is high (about US\$ 0.205 per plantlet). The erratic supply, long distance transport of the delicate 
plantlets followed by reduced survival, the increasing demand of micropropagated plants with the subsequent procurement cost increment were found to be the major limitations for the profitability and sustainability of the microproagation technology. Therefore, this experiment was carried out with the objective to evaluate the effects of 6-benzylaminopurine (BAP) in vivo propagation of tissue culture raised sugarcane plantlets of three sugarcane genotypes (C132-81; C86-56 \& SP70-1284) with a view to complement microproagation technology and to ensure continuous supply, cut down the cost of plantlets procurement and propagation of sufficient amount of quality planting materials at the farm gate nursery within short period of time.

\section{Materials and methods}

\section{Area of study}

The study was carried out at Metahara sugarcane plantation, located at Eastern part of the country, at about $200 \mathrm{kms}$ away from Addis Ababa, Ethiopia. Metahara Sugar estate is situated at $8^{\circ} 53^{\prime} \mathrm{N}$ latitude and $39^{\circ} 52^{\prime} \mathrm{E}$ longitudes at an altitude of 950 m.a.s. with a semi arid climatic condition.

\section{Experimental materials}

The experimental materials were in vitro propagated sugarcane genotypes of C132-81, C86-56 and SP70-1284. The primary acclimatized plantlets of these sugarcane varieties were delivered with intact coco-peat from Mekelle Technology Institute Tissue Culture Laboratory and directly planted in white polyethylene bag ( $8 \mathrm{~cm}$ diameter with $10 \mathrm{~cm}$ height) filled with mixture of Luvisol, sand and compost in the ratio of $8: 2: 1$.

\section{Experimental design}

The experimental design was Completely Randomized Design with factorial treatment combination arrangements. Three sugarcane genotypes (C132-81, C86-56 and SP70-1284) with six levels of $\operatorname{BAP}\left(0,0.5,1,1.5,2\right.$ and $\left.2.5 \mathrm{mg} / 1 / \mathrm{m}^{2}\right)$ resulting in $3 \times 6=18$ treatment combinations each replicated three times. Each plot contains 30 pots (one plantlet a pot)

Table I Effects of genotype on the number of tillers and leaves per shoot and shoot length

\section{Data collections}

Data such as number of tillers per shoot, shoot length and number of active leaves per shoot were collected from ten randomly selected plantlets at $30^{\text {th }}$ and $60^{\text {th }}$ days of treatment application.

\section{Data analysis}

Then the average data were subjected to analysis of variance using SAS software version 9.2 while separation of significant means' was done using REGWQ (Ryan-Einot-Gabriel- Welsch) Multiple Range Test.

\section{Result and discussion}

Analysis of variance (ANOVA) proved that the interaction of 6-benzylaminopurine (BAP) and the sugarcane genotypes has a highly significant $(\mathrm{p}<0.001)$ effect on the number of tillers per shoot, average shoot length $(\mathrm{cm})$ and number of active leaves per shoot of the sugarcane genotypes tested: C132-81, C86-156 and SP70-1284 (Table 1). Similarly, comparison of the tested sugarcane genotypes showed significant variation both in the number of tillers per shoot and number of leaves per shoot. However, there was no statistically significant difference between the three sugarcane genotypes in average shoot length. In all the sugarcane genotypes, the lowest number of tillers per shoot, average shoot length and number of leaves per shoot were obtained on the control treatment ( $0 \mathrm{mg} / \mathrm{l} \mathrm{BAP})$. However, the maximum result for all the response variables tested was observed at $1 \mathrm{mg} / 1$ and $1.5 \mathrm{mg} / 1$ of BAP. In sugarcane genotype C132-81, the lowest number of tillers per shoot (1.97), average shoot length $(27.67 \mathrm{~cm})$ and number of leaves per shoot $(4.5)$ was obtained at 0mg/l BAP (control). But, increase in the concentration of BAP from 0 up to $1 \mathrm{mg} / \mathrm{l}$ BAP showed an increasing trend for all the response variables tested: number of tillers per shoot, average shoots length and number of leaves per shoot (Table 2). The maximum number of tillers per shoot (4.00) and average shoot length $(30.67 \mathrm{~cm})$ were recorded on $1 \mathrm{mg} / 1 \mathrm{BAP}$ while the maximum number of leaves $(6.00)$ was obtained at 0.5 and $1 \mathrm{mg} / 1$ for the sugarcane genotype C13281. However, further increase in the concentrations of BAP beyond $1 \mathrm{mg} / 1$ showed no positive effect for all the response variables tested in C132-81 (Table 2).

\section{Response variable (Mean $\pm \mathrm{SE}$ )}

\begin{tabular}{llll} 
Genotypes & & & \\
\cline { 2 - 4 } & Number of tillers/shoot & Average shoot length(cm) & Number of leaves/shoot(cm) \\
\hline SP70-1284 & $3.86^{\mathrm{a}} \pm 0.21$ & $29.00^{\mathrm{a}} \pm 0.68$ & $6.00^{\mathrm{a}} \pm 0.09$ \\
$\mathrm{CI} 32-81$ & $2.94^{\mathrm{b}} \pm 0.21$ & $28.83^{\mathrm{a}} \pm 0.68$ & \\
& & & \\
& & & \\
C86-156 & $2.57^{\mathrm{b}} \pm 0.21$ & $29.50^{\mathrm{b}} \pm 0.68$ & $6.28^{\mathrm{a}} \pm 0.09$ \\
\end{tabular}


Table 2 The Effect of 6-benzylaminopurine on the number of tillers per shoot, number of leaves per shoot and average shoot length of sugarcane genotypes

\begin{tabular}{|c|c|c|c|c|c|c|c|c|c|}
\hline \multirow[b]{2}{*}{ BAP(mg/l) } & \multicolumn{3}{|l|}{ CI32-8I } & \multicolumn{3}{|l|}{ C86-I56 } & \multicolumn{3}{|l|}{ SP70-I 284} \\
\hline & $\begin{array}{l}\text { Number } \\
\text { of } \\
\text { tillers/ } \\
\text { shoot }\end{array}$ & $\begin{array}{l}\text { Average } \\
\text { shoot } \\
\text { length }(\mathrm{cm})\end{array}$ & $\begin{array}{l}\text { Number } \\
\text { of leaves/ } \\
\text { shoot }\end{array}$ & $\begin{array}{l}\text { Number } \\
\text { of tillers/ } \\
\text { shoot }\end{array}$ & $\begin{array}{l}\text { Average } \\
\text { shoot } \\
\text { length }(\mathrm{cm})\end{array}$ & $\begin{array}{l}\text { Number } \\
\text { of leaves/ } \\
\text { shoot }\end{array}$ & $\begin{array}{l}\text { Number } \\
\text { of tillers/ } \\
\text { shoot }\end{array}$ & $\begin{array}{l}\text { Average } \\
\text { shoot } \\
\text { length }(\mathrm{cm})\end{array}$ & $\begin{array}{l}\text { Number } \\
\text { of leaves/ } \\
\text { shoot }\end{array}$ \\
\hline 0 & $1.97^{d}$ & $27.67^{d}$ & $4.5 .00^{c}$ & $1.73^{d}$ & $28.00^{c}$ & $6.00^{\mathrm{b}}$ & $2.50^{d}$ & $24.67^{e}$ & $5.33^{d}$ \\
\hline I & $4.00^{\mathrm{a}}$ & $30.67^{\mathrm{a}}$ & $6.00^{\mathrm{a}}$ & $3.00^{\mathrm{b}}$ & $31.33^{\mathrm{a}}$ & $6.33^{b}$ & $4.33^{b}$ & $32.67^{\mathrm{a}}$ & $6.53^{\mathrm{a}}$ \\
\hline 1.5 & $3.00^{\mathrm{b}}$ & $29.33^{b}$ & $5.33 .00^{\mathrm{a}}$ & $3.53^{\mathrm{a}}$ & $29.33^{b}$ & $7.00^{\mathrm{a}}$ & $4.67^{\mathrm{a}}$ & $29.33^{c}$ & $6.33^{b}$ \\
\hline 2 & $3.00^{\mathrm{b}}$ & $28.00^{c}$ & $5.00^{\mathrm{b}}$ & $2.00^{c}$ & $29.33^{b}$ & $6.00^{\mathrm{b}}$ & $4.00^{b}$ & $30.67^{b}$ & $6.00^{\mathrm{b}}$ \\
\hline 2.5 & $2.33^{c}$ & $29.00^{\mathrm{b}}$ & $5.33^{\mathrm{b}}$ & $2.33^{c}$ & $29.33^{\mathrm{b}}$ & $6.00^{\mathrm{b}}$ & $3.33^{c}$ & $29.00^{c}$ & $5.67^{c}$ \\
\hline$C V$ & 8.7 & 9.9 & 6.5 & 8.7 & 9.9 & 6.5 & 8.7 & 9.9 & 6.5 \\
\hline
\end{tabular}

Remark: Means with the same letter are not significantly different at 0.05 probability level.

In sugarcane genotype C86-156, the maximum number of tillers per shoot (3.53) and number of leaves per shoot (7.00) was obtained at $1.5 \mathrm{mg} / \mathrm{l} \mathrm{BAP}$ while the maximum average shoot length was observed at $1 \mathrm{mg} / 1$ (Table 2). In sugarcane genotype SP70-1284, the maximum average shoot length $(32.67 \mathrm{~cm})$ and highest number of leaves per shoot (6.53) was obtained at $1 \mathrm{mg} / 1$ BAP while the maximum number of tillers per shoot was observed at 1mg/l BAP (Table 2). Increase in concentrations of BAP beyond the optimum levels showed no any significant increment in the response variables tested (Table 2). The lowest number of tillers per shoot, average shoot length and number of leaves per shoot observed on the treatment lacking the plant growth regulator BAP (control) could be due to the role of BAP in enhancing cell division that will in turn promote plant growth and development (tillering, shoot elongation and leaf development). Thus, lack of BAP in the control treatment produced the lowest response variables among the other treatments containing BAP. Increase in the concentration of BAP increased the response variables to the optimum levels and showed a declining effect. This could be due to the fact that increased levels of BAP beyond the optimum level hampers cell division and deleterious to plant cell. The result obtained in this study is different from the study results reported by ${ }^{2}$ at Tana- Beles Sugar Development Project on Sugarcane genotypes B52-298 and NCo-334 treated with trimming $1 / 3$ of the leaves, DAP fertilizer at $0.16 \mathrm{gm} \mathrm{L}^{-1} \mathrm{~m}^{-2}$ and plant growth regulators $\mathrm{GA}_{3}, \mathrm{BAP}$ and kinetin each at $0.04 \mathrm{mg} \mathrm{L}^{-1} \mathrm{~m}^{-2}$. On these treatment combinations, B52-298 gave $6.45 \pm 0.51$ tillers per shoot with $4.39 \pm 1.44 \mathrm{~cm}$ average shoot length and $5.12 \pm 0.23$ leaves per shoot while NCo-334 produced $5.77 \pm 0.79$ tillers per shoot with $7.21 \pm 0.11 \mathrm{~cm}$ average shoot length and $5.51 \pm 0.05$ leaves per shoot. Similarly, N14 gave $5.36 \pm 0.55$ tillers per shoot with $5.71 \pm 0.15 \mathrm{~cm}$ average shoot length and $5.41 \pm 0.30$ leaves per shoot on the same treatment combination.

\section{Conclusion}

The traditional method of sugarcane propagation has many limitations while microproagation technology is potent to solve all the limitations except it is costly to produce or procure the plantlets. Hence, in vivo propagation technology (IVPT) was developed to complement tissue culture technology, but reproducibility of the
IVPS protocols is dependent on the genotype, environmental weather conditions, soil mixture, plant growth regulators and interaction of factors used. Treatment combination containing $1 \mathrm{mg} / 1$ BAP and $1.5 \mathrm{mg} / 1$ gave optimum propagation responses. Sugarcane genotype C132-81 4 tillers per shoot with $30.67 \mathrm{~cm}$ average shoot length and 6 active leaves per shoot while C86-56 produced $3.53 \& 4.67$ tillers per shoot, $29.33 \mathrm{~cm}$ average shoot length and $7.0 \& 6.33$ active leaves per shoot per month, respectively. Thus, the current finding will help minimize the current challenges of sugarcane production by rapidly availing adequate amount of quality planting material of sugarcane while reducing the cost of plantlets procurement and hence the cost of sugar production.

\section{Acknowledgements}

None.

\section{Conflict of interest}

The author declares no conflict of interest.

\section{References}

1. Ridge R. IPI Bulletin No. 21: Fertilizing for High Yield and Quality-Sugarcane. Australia: IPI Publications; 2013. 117 p.

2. Tolera B. In Vivo proliferation of In Vitro propagated sugarcane (Saccharum officinarum L.) genotypes at Tana- Beles sugar development project, North-Western Ethiopia. Cell Dev Biol. 2015;4:161.

3. Tolera B, Diro M, Belew D. Response of sugarcane (Sacharum officinarum $\mathrm{L}$.) varieties to BAP and IAA on In vitro shoot multiplication. Adv Crop Sci Tech. 2014;2:126.

4. Ahloowalia BS, Prakash J, Savangikar VA, et al. Low cost options for tissue culture technology in developing countries: proceedings of a technical meeting organized by the joint FAO/IAEA division of nuclear techniques in food and agriculture and held in Vienna 26-30 August 2002. Austria: Vienna : International Atomic Energy Agency; 2002. $106 \mathrm{p}$.

5. Lal N, Krishna R. Sugarcane and its problems: Tissue culture for pure and disease free seed production in sugarcane. Indian sugar. 1994;44:847-848. 
6. Lorenzo JC, Ojeda E, Espinosa A, et al. Field performance of temporary immersion bioreactor derived sugarcane Plants. In Vitro Cell Dev Biol Plant. 2001;37(6):803-806.

7. Krishnamurthi M, Tlaskal J. Fiji disease resistant: Saccharum officinarum L.var. Pindar sub clone from tissue culture. Proc ISSCT. 1994;13:130-137.

8. Sreenivasan TV, Sreenivasan J. Microproagation of sugarcane varieties for increasing cane yield. SISSTA Sugar J. 1992;18:61-64

9. Anonymous. Microproagation: A Tissue culture technique in sugarcane. India: Indian institute of sugarcane research; 2002.

10. Ibrahim M, Tolera B, Aman J, et al. Evaluation of Tissue culture raised sugarcane planting materials against their donor conventional seed sources as initial sources of seed cane at Tendaho sugar development project, North-Eastern Ethiopia. J Hortic. 2016;3:168.
11. Sood N, Kumar Gupta P, Srivastava RK, et al. Comparative studies on field performance of micropropagated and Conventionally propagated sugarcane plants. Plant Tissue Cult \& Biotech. 2006;16(1):25-29.

12. Comstock JC, Miller JD. Yield comparison: Disease free tissue cultures versus bud propagated planted sugarcane plants and healthy versus yellow leaf virus infected plants. Journal American Society Sugar Cane Technologists. 2004;24:31-40.

13. Cox M, Hogarth M, Smith G. Cane breeding and improvement. In: Hogarth M, et al. editors. Manual of cane growing. Bureau of Sugar Experimental Stations, Australia; 2000. p. 91-108.

14. Geetha S, Padmanabhan D. Effect of hormones on direct somatic embryogenesis in sugarcane. Sugar Tech. 2001;3(3):120-121. 